\title{
Thought Presentation in Alice Sebold's The Lovely Bones
}

\author{
Shahid Ahmad \& Shanthi Nadarajan \\ eng.language@yahoo.com,nshanthi@unimas.my \\ Department of English, Universiti Malaysia Sarawak, MALAYSIA
}

\begin{abstract}
The last three decades have witnessed an increasing interest in the studies of thought presentation in stream-of-consciousness narratives among linguists (Semino \& Short, 2004; Leech \& Short, 2007; Bray, 2014; Fludernik, 1993). Largely because fictional writers use thought presentation in various ways to get readers to understand direct and indirect thoughts of the characters. Feminist writers have employed thought presentations in stream-of-consciousness narratives to give voice to the sufferings and yearnings of women and children. It has been done through careful selection of language that includes lexical choices, grammatical categories, and meaning representation. Besides providing multiple perspectives to the character's experiences through definition, reasoning, and arguments, the use of differentiated meanings and metaphorical language in thought presentations has served as insights into the minds of killers and criminals. This paper uses stylistic analysis to explore the conscious and sub-conscious thought presentations of Susie Salmon, the protagonist, and Mr. Harvey, the antagonist in Alice Sebold's The Lovely Bones (2002). For the study, the researchers use Geoffrey Leech and Michael Short's (2007) model of thought presentation.

The analysis will delve into the thought patterns of 'dead' Susie when she meets her assailant. It investigates lexical selection, semantics, and linguistic patterns. The findings show that thought patterns residing even in the sub-conscious or unconscious of human beings can be reached by analyzing thought representations embedded in a narrative discourse through a variety of thought presentation techniques. The central assumption being that while it takes courage to write about death and rape, it takes imagination to a new realm when a 'dead' girl returns to talk about her rape and death.
\end{abstract}

Keywords: thought presentation, sexual violence, stylistic analysis

\section{Introduction}

The past three decades have seen the presentation of characters' words and thoughts to be as important aspects of fictional narratives, and have received widespread attention among linguists (Semino \& Short, 2004; Leech \& Short, 2007; Bray, 2014; Fludernik, 1993). Serving as counterpoints to speech presentations, thought presentations' values are accentuated when reports of conventional exchanges become punctuated with the presentation of thoughts of one or more characters in writing. Often related to information, beliefs, or attitudes of the characters, thought presentations are used when characters are not able to express their feelings openly for some reason. In this sense, this may be in contrast with what characters do or say (Cohn, 1978). Leech and Short (2007) confirm that thought presentation is not an attempt to merely report what the characters think, but also render their immediate experiences to the consciousness of thoughts.

Initially coined by the American psychologist William James in his research, The Principles of Psychology (1890), the concept of 'Stream of Consciousness' denotes the seamless 
flow of thoughts and awareness of the human mind. Nawale (2010) states that "the writer attempts by the Stream-of-Consciousness technique to reflect all the forces, external and internal, influencing the psychology of a character at a single moment" (p. 39). In other words, the representations of thoughts in stream-of-consciousness fiction comprise several linguistic choices that mirror the characters' thought processes. Being accustomed to the functions of the linguistic opportunities, a reader directly experiences the flow of thoughts in the characters' minds and gains indirect access to personal and most private thoughts. Used well, thought presentation techniques allow writers to turn concrete experiences in a novel to abstract through careful choice of words, meanings, and discourse.

Discourse on rape and violence abounds in fiction. Feminist writers have not kept silent about rape and violence. Feminist writing goals in the 1970s have been to give a voice to the 'silence' surrounding rape and violence, and to raise social awareness. Several writers have used stream-of-consciousness narratives to give voice to the inner conflicts of the female mind and to describe the sufferings from the character's point of view. Five decades later, as the rape culture continues to bombard society, more needs to be done. It is important to examine literary narratives on rape, and explore how society plays a part in reinforcing this culture. Stream-ofconsciousness fiction, in particular, has dealt with narratives portraying the unspoken thoughts and feelings of characters without resorting to extended psychological narratives or extended representations of multifarious thoughts. An insight into some groundbreaking works of stream-of-consciousness narratives and works on thought presentation can serve as fertile ground for gauging their importance for exploring difficult and sensitive themes in fiction. The present study is intended to stylistically explore the narrative discourse of a raped and dead girl in Alice Sebold's The Lovely Bones.

Stylistics is a branch of linguistics that studies the various characteristics of the language (Bullock, Stallybrass \& Trombley,
1988) in writings. According to Hoover (2008), stylistics rests upon a distinction between 'what is said' and 'how it is said.' Widdowson (2003) stylistically analyzes the use of the verb "have" in the sentence 'I have promises to keep' in Robert Frost's Stopping by Woods on a Snowy Evening. As a lexical verb, 'have' carries the meaning of possession, but as a modal auxiliary (as used in the sentence), it carries the meaning of obligation. In the expression 'I have promises to keep,' these two senses of 'have' are compounded. What is being suggested here is that the first person in the poem has made several promises, but the possession of promise does not bestow rights, rather it imposes obligations (p. 120). It shows that rendering 'style' in the literary texts is a phenomenal technique for writers to manipulate meanings therein.

Brown and Gilman (1960) explored the use of the pronoun "you" to many persons and "you" as to one person signifying two dimensions fundamental to the analysis of social life - the dimension of power and solidarity. Their argument is based on the rationale that semantic and stylistic analysis of such forms has relevance for psychology, sociology, linguistics, and literature. The premise is that a person has power over another when he can control the behavior of another e.g. when the superior says 'You will', and receives 'I'. This power can be in the form of physical strength, age, sex, or within the family. Then, not all differences between a person can imply a difference of power. Some modes of address intrude into consciousness as a problem at times of status change.

The study of speech and thought presentation is central to stylistics (Banfield, 1973; McHale, 1978; Fludernik, 1993; Leech \& Short, 1981, 2007). As Leech and Short (2007) define, with stylistics being the study of style; it is how meaning gets negotiated (e.g., lexical and grammatical) in discourse. Within this, thought presentation technique is construed as a unique approach to understanding the thought processes of its characters. In the pursuit of accessing the consciousness of the characters, Gregoriou (2002) investigates the metaphorical 
language of serial killers in James Patterson's two novels named Along Came a Spider (1993), and Cat and Mouse (1997). Gregoriou discovered that serial killers' figurative conceptualizations of experiences appear to be motivated by underlying metaphorical schemes of thought that constrain, even define, the way killers think, reason, argue, and carry out their criminal actions (ibid).

The works of Virginia Woolf come to mind when examining the novelists who adopted the techniques of thought presentation in their stream-of-consciousness fiction. Woolf gave voice to the complex inner world of feelings and memories and conceived the human personality as a continuous shift of impressions and emotions. In Mrs. Dalloway (1925) and To the Lighthouse (1927), the omniscient narrator disappears, and the point of view shifts inside the characters' minds through flashback, associations of ideas, momentary impressions presented as a continuous flux. Other noteworthy authors being James Joyce, William Faulkner, etc. produced peculiar works. Ulysses (1922), written by Joyce, serves as a complex evocation of the inner states of the characters, i.e., Leopold, Molly Bloom, and Stephen Dedalus. Similarly, Faulkner's The Sound and the Fury (1929) records fragmentary and impressionistic responses in the readers' minds about the three members of the Compson family to events that are immediately being experienced or events that are being remembered.

Guo (2017) studied the thought presentation patterns of 'free indirect thought' in Woolf's Mrs. Dalloway (1925). The study investigated the functions of cohesive ties in discourse to analyze the thought process and the distinctive personality of a character. Guo concluded that reality is blended with the memories in a morning scene of Clarissa Dalloway's life when she recollects her thoughts, and cohesive ties help to focus the reader's attention on some semantic concepts and offer clues to their interpretation of the character's thought process (ibid). Cui (2014) also studies Mrs. Dalloway (1925) through a perspective of parenthetical shifts and the presentation of multi-personal consciousness in speech and thought presentation in stream-ofconsciousness. Cui (2014) suggests that the syntactic independence of a parenthetical gives it a degree of freedom to digress from its host, which makes this construction a convenient device to bring in new sources of consciousness and thus shifts the narrative viewpoint from one character to another (ibid). In her prominent studies in speech and thought presentation, Semino (2004) went further and interpreted the choices, patterns, and subtle variations in the presentation of characters' thoughts in an extract from Julian Barnes' England, England (1998). Semino's findings showed that the linguistic choices affect the reader's perception and potential empathy with the characters involved (ibid).

The concept of consciousness has been investigated through multiple approaches related to thought presentation to get readers to comprehend both the inner and physical world of characters and their point of view directly (Semino \& Short, 2004; Leech \& Short, 2007; Bray, 2014; Fludernik, 1993). As such, thought presentation has come to be inextricably linked with what is usually known as a stream of consciousness writing. According to Leech and Short (2007), the modes of speech and thought presentation are highly similar formally, but the presentation of thoughts of characters, even in an extremely indirect form (i.e., narrative report of thought acts [NRTA]) should be considered as an ultimate artifice.

Emphasizing the significance of the representations of thought in the narrative discourse, Bonheim (1982) states that rather more intricate than representations of speech in direct or indirect mode are the representation of thoughts, which can be conceptualized as a kind of silent speech or inner speech. Leech and Short (2007) find that in the presentation of speech, the use of direct speech (DS) or free direct speech (FDS) produces the impression that a character is talking in the presence of an audience, with less authorial intervention. Similarly, direct thought (DT) and free direct thought (FDT) authorial intervention appear minimal; but since the result 
is effectively a monologue, with the character 'talking' to oneself, these innermost thoughts of the character produces and acquires a conscious quality. For example, Sebold using 'free direct thought' technique portrays the thoughts of a rape victim in Lucky (2002):

I will always think of her when I think of the pink hair tie. I will think of a girl in the last moments of her life (p. 11).

Appearing at the opening page of the memoir where a girl gets brutally beaten and raped in a tunnel, the technique builds character through flashbacks of a previous rape event which the victim had heard about. By situating the rape event at the same place, the writer succeeds in creating a connection and creates a surreal feeling in the reader. The representation of the victim's innermost thoughts as she goes through the ordeal via 'free direct thought' mode provides a window for a reader to reach out to the character's consciousness as she goes through the same experience of fear, shock, and sad disposition. The emphasis on the verbs 'think' carries the meaning of three levels of thought-a direct association with a former victim who had been less lucky. There is the added image of hair tied in pink, which is emblematic of life, youth, and the deliberate use of 'pink', which represents girls' color "sugar and spice and everything nice."

\section{I will always think of her I think of the pink hair ... I will think of a girl in the last moments of her life.}

The third level would be a sense of insecurity - to feel and imagine her death. The repetitions and emphasis are meant as recollections about the former less 'lucky' victims who had life and death experiences, and this also invokes images of heaven and hell.

Alice Sebold stands among the few writers who experienced rape and went on to write about death and rape. The Lovely Bones (henceforth $T L B$ ) is an example of American popular culture which revolves around Susie
Salmon, a fourteen-year-old teenager who is raped and murdered by her neighbor. The story develops further when Susie, who narrates her own story using the first-person point of view, continues to maintain her awareness to the affairs surrounding her death and the life of people that are closely related to her, including the person that murdered her, George Harvey. Sebold's narrative therefore, not only serves as a voice that makes sense of her own experience but also situates her experience in a larger framework that serves large goals. The memories of the dead girl who returns to tell her tale of her sexual assault to become an entire realm of fiction and far away from any courtroom discourse. The first chapter opens and ends the main character's life with the following lines:

My name was Salmon, like the fish; first name, Susie. I was fourteen when I was murdered on December 6, 1973 (p. 5).

As Brison (2002) mentions, sexual violence should be defined for the person at the receiving end of the violence. The main character begins her story with her eulogy. By using the subject pronouns 'my,' 'I,' and situating them in the past tense 'was,' she prepares the reader from the very beginning for what is about to become the end of her life. Following her murder, young Susie opens her eyes in heaven, only to find heaven incomplete without her family and loved ones. Feeling trapped in an otherwise 'perfect' heaven, she appears and reappears on earth periodically.

According to Buffachi and Gilson (2016), unlike the initial act of violence, which terminates a victim's life, the experience of violence cannot be defined in temporal terms alone, as the ripples of violence that follow from the initial act continue long after the act. In Sebold's Lucky, the main character lives on only to suffer in silence as her shattered family members try to come to terms with the event. In $T L B$, dead Susie "returns" to see her family breaking up, as each member struggles to move on. Through a series of flashbacks, interchanging episodic memories of past and present life on 
earth, and heaven, the main character manages to narrate the story into a complete whole.

Thought in fiction is also represented similar to speech using direct or indirect discourse. Leech and Short (2007) outlined five linguistic techniques to the narrator to present the characters' conscious and subconscious thoughts namely: direct thought (DT), free direct thought (FDT), indirect thought (IT), free indirect thought (FIT), and narrative report of thought acts (NRTA) (Refer Table 1).

In The Almost Moon (2008), Sebold uses 'direct thought' and 'free direct thought' techniques to reflect the consciousness of mindful acts of a daughter who kills her mother in a fit of rage after having taken care of her for years.

Help doesn't come free, I felt like telling her (DT). These people owe you nothing (FDT) (p.6).

In $T L B$, the 'indirect thought' technique describes Susie's grandmother's thoughts:

She thought suddenly that she would do nothing but sympathize with her daughter (p. 172).

When Susie's father comes to know about Susie's murder, his apprehension is expressed via 'free indirect thought':

\section{How could he tell that to Abigail? (p. 20)}

In Lucky (2002), Sebold uses the 'narrative report of a thought act' technique to exhibit the thought process of her father when she narrates her father's reaction after being told of the rape incident:
"But how could he have raped you unless you let him?"

"That would be like saying I wanted it to happen."

"But he didn't have the knife in the tunnel."

"Dad," I said, "think about this. Wouldn't it be physically impossible to rape and beat me while holding a knife the whole time?"

He thought for a second and then seemed to agree (NRTA) (p. 67).

The above instances suggest that the writer often decides to allow the audience to follow through the thought patterns of a character (if at all). By the use of thought act reporting, the writer is inviting the audience to see things from the character's point of view. The linguistic choices in the thought presentation techniques, therefore, function as a roadmap to reach the emotions, perceptions, and experiences of the characters. In line with these perspectives, this paper aims to provide a stylistic analysis of the representations of thoughts and explores the thought processes of two main characters in TLB: the fourteen-year-old rape victim, Susie Salmon, and Mr. Harvey, the perpetrator.

\section{Methodology}

Leech and Short's $(1981,2007)$ model of speech and thought presentation has continued to influence stylistic analysis for over three decades. Leech and Short's careful distinguishing of two separate, parallel scales of speech and thought presentation includes categories defined by both formal and contextual features. It allows researchers to investigate the varying effects of slight changes in point of view, and to analyze shifts in degree of 'faithfulness' to the original thought or utterance precisely (ibid). The original categories of speech and thought presentation proposed by Leech and Short (2007) are tabulated below: 
Table 1.

Thought Presentation Techniques

\begin{tabular}{|l|l|}
\hline \multicolumn{2}{|l|}{ Thought Presentation } \\
\hline Direct Thought (DT) & $\begin{array}{l}\text { In Direct Thought (DT), the thought of the character is } \\
\text { reproduced verbatim by the narrator. }\end{array}$ \\
\hline Free Direct Thought (FDT) & $\begin{array}{l}\text { Free Direct Thought is like Direct Thought (DT) but with } \\
\text { the introductory reporting clause is removed. }\end{array}$ \\
\hline Free Indirect Thought (FIT) & $\begin{array}{l}\text { Indirect Thought (IT) has an introductory reporting clause, } \\
\text { explicit subordination, and a declarative form for the } \\
\text { reported clause. }\end{array}$ \\
\hline $\begin{array}{l}\text { Free Indirect Thought (FIT) differs from Direct Thought } \\
\text { of the first-person pronoun to the third person (indirect } \\
\text { features) and also by the absence of a reporting clause and } \\
\text { the retention of the interrogative form and question mark } \\
\text { (direct features). }\end{array}$ \\
\hline $\begin{array}{l}\text { Narrative Report of a } \\
\text { Thought Act (NRTA) }\end{array}$ & $\begin{array}{l}\text { Narrative Report of a Thought Act (NRTA) incorporates } \\
\text { what minimal report there is within the main clause by } \\
\text { nominalizing the reported clause. }\end{array}$ \\
\hline
\end{tabular}

The above techniques of thought presentation suggest that fictional characters' points of view can be represented without the state of their mind being described. Rather, the writer depicts scenes and events as they appear within the viewpoints of the characters concerned. The instances of thought representations for interpretation are extracted from the narrative discourse of Susie Salmon when she is with the rapist in the opening chapter in $T L B$. The analysis will explore seven extracts of language use in terms of word choice, grammatical categories, and representation of meanings.

\section{Findings and Discussion}

Susie introduces herself in the opening lines of $T L B$ as fourteen, and that she was murdered. In the fourth paragraph, she introduces her murderer to the audience as follows:

\section{Extract 1}

My murderer was a man from our neighborhood (NRTA). My mother liked his border flowers (FIT), and my father talked to him once about fertilizer (FIT).
The language is that of a teenager with a limited worldview that revolved around family, her neighborhood, and the books she reads. By using concrete nouns with the possessive pronouns such as 'my' and 'our,' i.e., 'my murderer,' 'my mother,' 'my father' and 'our neighborhood,' the narrator directly addresses the murderer. The neighbor Mr. Harvey is known to her, her mother, and to her father. She does not view Mr. Harvey as dangerous because the mother likes his 'flowers,' and his father has talked to him. The use of concrete object words 'border,' 'flower,' 'fertilizers' are a means of demonstrating that despite the seemingly pretty sight of flowers above the ground, the stinking fertilizer was probably a better description of the neighbor.

\section{Extract 2}

It was dark and cold outside while Susie was returning home from junior high school. She was startled to see Mr. Harvey in a cornfield. She narrates:

Six feet from where Mr. Harvey stood (NRTA), I stuck my tongue out to taste a snowflake (FDT). 
There is an emphasis on 'six feet' by being placed at the beginning of the sentence. The 'six feet' term is associated with the normal depth of a grave. Susie is also killed on December 6. There are six steps down into the hole.

\section{Extract 3}

Mr. Harvey invites Susie to visit the hole he had built in the ground. To lure the girl, he described it as a kind of clubhouse for children in the neighborhood.

Mr. Harvey was looking at me strangely (FIT)... His glasses were small and round with gold frames, and his eyes looked out over them and at me (NRTA).

Through the use of the verb 'look' and the pronoun 'me', the writer adds emphasis to the act of scrutiny. The verb 'looking at me' and 'looked out over them' and 'at me' adds additional intensity. The use of the adverb 'strangely' however, adds depth to the act of looking. It depicts the dual act of gazing and thinking about the object-cum-specimen. His strange look suggests the act of wanting to touch, inspect, experiment and dissect the object. It could also represent some sort of craving. The personification of his eyes plays up the fact that Mr. Harvey was 'hungry' for sex and wanted to satisfy his desire as soon as possible.

\section{Extract 4}

It was a narrow hole, and there was insufficient space to move around. While Susie could almost stand up, Mr. Harvey was forced to stop. Susie describes:

He could have been the hunchback of Notre Dame (FIT), whom we had read about in French class (FDT).

Susie's lack of experience is reflected when her flashback only extends to a fairytale character who walked around with a hunch on his back. The fact that the 'hunchback' in Victor Hugo's novel Notre Dame (1831) lived a tortured life, and his character was embodied in his twisted spine needs to be considered here. The association of the Notre Dame's hunchback with Mr. Harvey is meant to be an abstraction that Mr. Harvey probably shared a torturous, twisted past and had similar characteristics.

\section{Extract 5}

The fact that Mr. Harvey had planned it all, and had no intention to show her around is indicated in the following instance:

\section{He immediately sat down (NRTA).}

The room was small, and he wanted to make sure that the girl did not escape. The adverb 'immediately' refers to some of the levels of urgency and impatience. He wanted to block her path up, he wanted to snare his prey and invites her to look around.

\section{Extract 6}

After drinking Coke unwillingly, Susie pleaded to go home. Mr. Harvey made her feel skeevy and icky while he was blocking the door. Susie narrates:

He stood up and did his hunchback number by the six dig-in steps that led to the world (NRTA).

The repetition of the number 'six'. There were six steps to the world outside. It creates an image of a grave and the positioning of Mr. Harvey as in charge.

\section{Extract 7}

Mr. Harvey becomes impatient and orders Susie to take off her clothes. She is raped. He decides to kill her later. Helpless, Susie describes:

When I would not (FDT) - was it only that, only that I would not follow his suggestion? (FDT) - he leaned to the side and felt, over his head, across the ledge where his razor and shaving cream sat (FIT). He brought back a knife (NRTA). Unsheathed, it smiled at me, curving up in a grin (NRTA). 
He took the hat from my mouth (NRTA). The assailant is shown to have masterminded the event. Being a serial killer ahead of everyone, he tries to make sure that he wants absolute power over Susie. At some point, Susie tries to resist to demonstrate agency. There is an emphasis on select words e.g., 'I would not,' 'I would not follow'. By denying the rapist's demand for her to get up, she is resisting. She assumes that her refusal to obey his request was a reason for his decision to kill her. However, the end still comes. When the victim is unable to move, the hunter takes out his knife to cut her up the body into pieces. Susie stops moving, but this is reciprocated by an unusual number of actions by the assailant, e.g., leaned to the side, felt over his head, brought back a knife, smiled, curved up a grin. The author avoids extensive explanations on Susie's state of mind; rather, she quickly fills out the assailant's psychotic plots and ends her ordeal.

The paper explored the thought presentation techniques in stream-ofconsciousness writings. The analysis focused on the after death thought presentation of the dead Susie Salmon when she met Mr. Harvey. The multiple representations of thoughts through flashbacks and memories serve as a window into the inner and physical world of girls who have not been 'lucky'. Hearing the story through the dead girl's own story, the author gets to shape her story free from the interference of other characters' views and the legal system, while simultaneously offering an insightful way of understanding how children can easily be lured by people they know and end up being raped.

The thought presentation also provided some insights into the behavior of the criminal mind of Mr. Harvey. It is arguable that writers, when they select words to portray the criminal mind, are providing access to the criminal's conceptualization of reality after given that language is reflective of man's perceptual and conceptual understanding of experience. It is often seen as a key to demystifying criminal behavior. People with criminal records are thought of as unconventional, antisocial, unusual, and unexpected. It is possible that writers do attempt to demystify this by offering some access to the criminal's world or reality, where their crimes are justified and accounted for. Indirectly, we are, to some extent being placed in a position where we get to understand the criminals, share their past secrets, and sometimes be forced to think over their behavior and course of actions.

The representations of thoughts in a narrative discourse are brimmed with various perspectives of characters to experiencing the lives. Therefore, it can be argued that it is through the careful study of thought presentation that we get to understand humanity. In $T L B$, it must be said that the novel is masterfully etched, with care given to poetic language and minimal sentimentalism. It is never easy to talk about rape and death, but through careful construction of flashbacks and interlay of words, the author succeeds in bringing about systemic thinking.

\section{Conclusion}

It has been analyzed and discussed that thought presentation is a significant way to comprehend the characters' thought processes in stream-of-consciousness fiction. Writers incorporate the multiple modes of thought presentation to demonstrate effectively the life experiences of their characters precisely beyond what they utter openly. The linguistic opportunities therein function as scattered clues and patterns which cohesively contribute to the overall personalities of the characters and their experiences. It is including both the inner and physical worlds. In the case of Sebold's TLB, the stylistic analysis shows that various techniques of thought presentation rendered in the narrative discourse offer several passages for readers to be in the main characters' minds to experience what they do in their points of view.

Additionally, the nexus of linguistic categories used to represent the actions and inactions of the characters in the novel offer chances to know the characters appropriately. Susie Salmon's point of view and linguistic choices display that she is innocent and inexperienced in recognizing the danger or evil about to come. Therefore, she could not judge Mr. 
Harvey and get easily trapped, which resulted in the abrupt end of her life. Contrarily, Mr. Harvey is a skilled inhuman nature who never hesitates to rape and silence his prey, even a child. The linguistic choices show that he possesses dual characters; being social, he establishes relations with families, and being a murderer, he lurks the children in the neighborhood to rape and terminate their lives. In a fatherly manner, he traps, torments, and tears out Susie's life. Thus, he is a cunning, quiet, evil monster who is also a cold-blooded, lying pedophile.

The paper stylistically exposes the linguistic clues and patterns which can be used to trace the consciousness of the evils and the victims in society. Eventually, it would be logical to say that the thought presentation techniques are crucial devices to be in the characters' minds, and, therefore, to effectively comprehend their various life experiences from their points of view.

\section{References}

Banfield, A. (1973). Narrative Style and the Grammar of Direct and Indirect Speech. Foundations of Language, 10, 1-39.

Bonheim, H. (1982). The Narrative Modes: Techniques of the Short Story. Cambridge [Cambridgeshire]: D.S. Brewer.

Bray, J. (2014). Speech and Thought Presentation in Stylistics. In M. Burke, The Routledge Handbook of Stylistics (pp. 222-236). New York: Routledge.

Brison, S. (2002). Aftermath: Violence and the Rethinking of a Self. Princeton, NJ: Princeton University Press.

Brown, R., \& Gilman, A. (1960). The Pronouns of Power and Solidarity. In T. Sebeok, Style in Language (pp. 253-76). Cambridge: MIT Press.
Bufacchi, V., \& Gilson, J. (2016). The Ripples of Violence. Feminist Review, 112, 27-40.

Bullock, A., Stallybrass, O., \& Trombley, S. (1988). The Fontana Dictionary of Modern Thought. London: Fontana Press.

Cohn, D. (1978). Transparent Minds: Narrative Modes for Presenting Consciousness in Fiction. Princeton NJ: Princeton University Press.

Cui, Y. (2014). Parentheticals and the presentation of multipersonal consciousness: A stylistic analysis of Mrs Dalloway. Language and Literature, 23(2), 175-187.

Fludernik, M. (1993). The Fictions of Language and the Languages of Fiction: The Linguistic Representation of Speech and Consciousness. Abingdon: Routledge.

Gregoriou, C. (2002). 'Behaving Badly': A Cognitive Stylistics of the Criminal Mind. Nottingham Linguistic Circular, 17, 61-73.

Hoover, D. L. (2008). Style and Stylistics. In H. Momma, \& M. Matto, A Companion to the History of the English Language (pp. 585595). Chichester, UK; Maiden, MA: WileyBlackwell.

Leech, G., \& Short, M. (1981). Style in Fiction: A Linguistic Introduction to English Fictional Prose. London; New York: Longman.

Leech, G., \& Short, M. (2007). Style in Fiction, $A$ Linguistic Introduction to English Fictional Prose (Second Edition). United Kingdom: Pearson Longman.

McHale, B. (1978). Free Indirect Discourse: A Survey of Recent Account. PTL, 3(2), 249287.

Nawale, A. M. (2010). Stream of Consciousness Technique: A Study of Arun Joshi's Fiction. Shodh, Samiksha aur Mulyankan 
(International Research Journal), 2(13), 3941.

Sebold, A. (2002). Lucky. London: Picador.

Sebold, A. (2002). The Lovely Bones. Great Britain: Picador.

Sebold, A. (2008). The Almost Moon. London: Picador.

Semino, E. (2004). Representing characters' speech and thought in narrative fiction: A Study of England, England by Julian Barnes. Style, 38(4), 428-451.

Semino, E., \& Short, M. (2004). Corpus Stylistics: Speech, Writing and Thought Presentation in a Corpus of English Writing. London: Routledge.

Widdowson, H. (2013). Stylistics and the Teaching of Literature. New York: Routledge. 